\title{
Citrate lyases of lactic acid bacteria
}

\author{
Sadja Bekal, Charles Diviès, Hervé Prévost* \\ Laboratoire de Microbiologie U.A. Inra, Ensbana, Université de Bourgogne, \\ 1, esplanade Érasme, 21000 Dijon, France
}

\begin{abstract}
Citrate lyase is a key enzyme of the citrate metabolism which is involved in flavor and texture of many fermented milk products. Citrate lyase which catalyses the cleavage of citrate into oxaloacetate and acetate is a multienzyme complex composed of three proteins: an acyl carrier protein (ACP); a citrate, acetate-ACP transferase; and a citryl-S-ACP lyase. The citrate lyase is active only when the thioester residue of the prosthetic group bound to ACP is acetylated. In the presence of citrate, the transferase mediates the formation of citryl-S-acyl carrier protein by acyl exchange and liberation of acetate. Then the lyase subunit cleaves the citryl-S-ACP with liberation of oxaloacetate and regeneration of the acetyl-S-ACP. In this review, the actual knowledge on the structure and regulation of citrate lyase in lactic acid bacteria (LAB) is presented in comparison to the enzymes characterized in others micro-organisms. The genetic organization of genes encoding proteins involved in citrate lyase activity of Leuconostoc mesenteroides is described. (C) Inra/Elsevier, Paris.
\end{abstract}

\section{citrate / citrate lyase / Leuconostoc / lactic acid bacteria}

Résumé - Les citrate lyases des bactéries lactiques. La citrate lyase est l'enzyme clé du métabolisme du citrate, qui joue un rôle important dans la flaveur et la texture de nombreux produits laitiers fermentés. La citrate lyase catalyse la réaction de clivage du citrate en acétate et oxaloacétate. Il s'agit d'un complexe multienzymatique composé de trois protéines : une acyl carrier protein (ACP), une citrate : acétate-ACP transférase et une citryl-S-ACP lyase. La citrate lyase n'est active que lorsque le résidu thioester du groupement prosthétique lié à l'ACP est acétylé. En présence de citrate, l'acyl transférase catalyse la formation d'un intermédiaire : le citryl-S-acyl carrier protein, en libérant de l'acétate. La citryl-lyase coupe par la suite l'acetyl-S-ACP, libère l'oxaloacéate et régénère de l'acetyl-S-ACP. Dans cette revue, nous présenterons les connaissances acquises sur la structure et la régulation des citrate lyases des bactéries lactiques. Nous décrirons ensuite l'organisation génétique des gènes structuraux qui codent pour les protéines impliquées dans l'activité citrate lyase de Leuconostoc mesenteroides. (c) Inra/Elsevier, Paris.

\section{citrate/ citrate lyase / Leuconostoc / bactérie lactique}

* Correspondence and reprints 


\section{INTRODUCTION}

Citrate is present in many substrates used in the food industry such as fruits, vegetables and milk. Citrate and sugar cometabolism by lactic acid bacteria (LAB) leads to the production of $\mathrm{CO}_{2}$ responsible for 'eye' formation in certain types of cheeses and of diacetyl which is considered as a main flavor compound of many fermented dairy products. Most of the knowledge on the metabolic pathways involved in citrate metabolism in lactic acid bacteria has been derived from Leuconostoc species and Lactococcus lactis subsp. diacetylactis. However, the regulation of the carbon flow from citrate to pyruvate is not understood. This can be achieved by characterization of genes involved in citrate metabolism and by understanding their regulation. The citrate utilization by lactic acid bacteria requires specifically three enzymes responsible for the conversion of citrate to pyruvate; a citrate permease, a citrate lyase and an oxaloacetate decarboxylase. The plasmidic genes citP encoding citrate permeases of Lactococcus lactis and Leuconostoc have been cloned and sequenced and shown to be identical $[9,23,37]$. Recent studies have described in detail the energetic advantage of citrate metabolism in Leuconostoc mesenteroides $[22,26]$ and the regulation of expression of Lactococcus citrate transport [24]. In Klebsiella, the biochemistry of the intracellular enzymes involved in the citrate utilization pathway, i.e., citrate lyase and oxaloacetate decarboxylase has been widely studied [13]. However, little information is available on the structure and regulation of these enzymes in LAB. In this paper, we review the actual knowledge concerning the citrate lyase in $\mathrm{LAB}$ in comparison to the enzymes characterized in other microorganisms. We report also some of our recent results on the characterization of citrate lyase of Leuconostoc.

\section{PROTEINS AND REACTIONS INVOLVED IN THE CITRATE LYASE ACTIVITY}

Bacterial citrate lyase [citrate oxaloacetate-lyase (pro- $3 \mathrm{~S}-\mathrm{CH}_{2} \mathrm{COO}^{-} \longrightarrow$ acetate) EC 4.1.3.6] occurs in a number of micro-organisms either as a citrate-induced or as a constitutive enzyme [35]. Citrate lyase catalyses the cleavage of citrate into oxaloacetate and acetate in the presence of divalent metal ions such as $\mathrm{Mg}^{2+}$ or $\mathrm{Mn}^{2+}$. Citrate lyase is a multienzyme complex composed of three proteins: an acyl carrier protein $(\gamma$-subunit, ACP) carrying a prosthetic group [11]; a citrate, acetate-ACP transferase ( $\alpha$-subunit, EC 2.8.3.10); and a citryl-S-ACP lyase ( $\beta$-subunit, EC 4.1.3.34) $[8,11]$. The breakdown of citrate to acetate and oxaloacetate involves two consecutive steps (figure 1). In the presence of citrate, the transferase mediates the formation of citryl-S-acyl carrier protein by acyl exchange and liberation of acetate. The second step is catalyzed by the lyase subunit which cleaves the citryl-S-ACP with liberation of oxaloacetate and regeneration of the acetyl-S-ACP. Only the lyase reaction has been shown to have an absolute requirement for divalent metal ions $\left(\mathrm{Mg}^{2+}, \mathrm{Mn}^{2+}, \mathrm{Zn}^{2+}, \mathrm{Fe}^{2+}, \mathrm{Co}^{2+}\right)$ (for review see [36]). The structure of the prosthetic group of citrate lyase purified from Klebsiella is a 5-phosphoribosyl-dephospho-coenzyme A attached by its ribose5-phosphate moiety via a phosphodiester linkage to a serine residue of the ACP [5, $12,29,30,34]$. The structure of the prosthetic group of citrate lyases can be assimilated to a covalently-bound coenzyme A or dephospho-CoA. The citrate lyase is active only when the thioester residue of the prosthetic group bound to its acyl carrier protein is acetylated. The acetylation of HS-ACP in the presence of ATP and acetate into the acetyl-S-ACP is catalyzed by a SH-citrate lyase ligase (CL-ligase, 


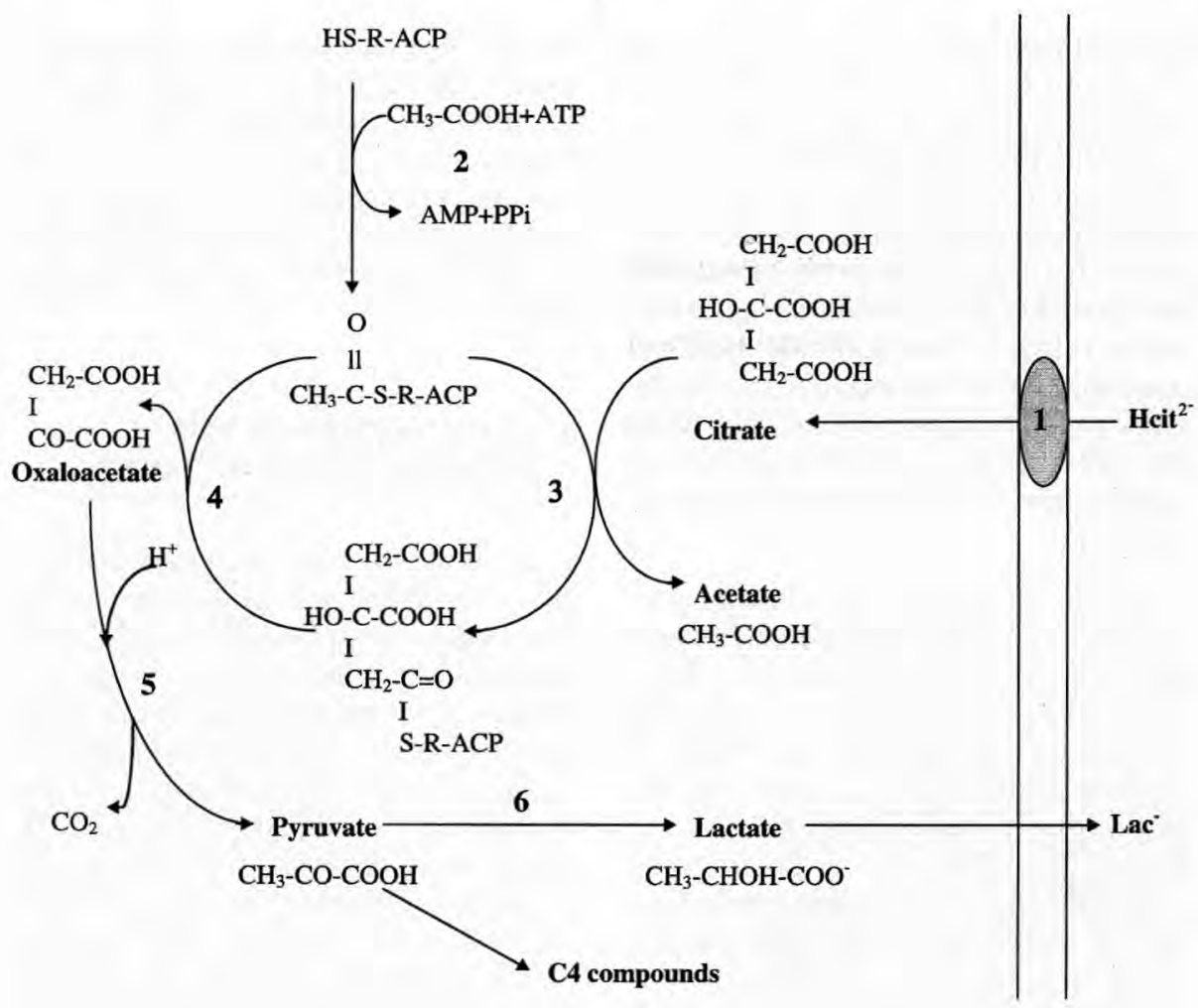

Figure 1. Citrate metabolism pathway in Leuconostoc mesenteroides and function of the different subunits of citrate lyase. 1) citrate permease; 2) SH-citrate lyase ligase, EC 6.2.1.22; 3) citrate:acetyl-ACP transferase, EC 2.8.3.10 (citrate lyase $\alpha$-subunit); 4) citryl-S-ACP lyase, EC 4.1.3.34 (citrate lyase $\beta$-subunit); 5) oxaloacetate decarboxylase; 6 ) lactate dehydrogenase; ACP: acyl carrier protein ( $\gamma$-subunit). $R$, prosthetic group.

Figure 1. Voie d'utilisation du citrate chez Leuconostoc mesenteroides et rôles des différentes sousunités de la citrate lyase. 1) : citrate perméase ; 2) SH-citrate lyase ligase, EC 6.2.1.22;3) citrate:acétyl-ACP transférase, EC 2.8.3.10 (sous-unité $\alpha$ ) ; 4) citryl-S-ACP lyase, EC 4.1.3.34 (sous-unité $\beta$ ) ; 5) oxaloacétate décarboxylase ; 6) lactate déshydrogénase ; ACP : acyl carrier protein (sous-unité $\gamma$ ) ; R : groupement prosthétique.

EC 6.2.1.22) $[1,7,18,20,28,31]$. Citrate lyase can be chemically activated by incubation of deacetylated citrate lyase with $\mathrm{N}$-acetyl immidazol or anhydride acetic. Enzymatic activity can also be restored without acetylation by acetyl-CoA which is a structure analogue of the acetylated prosthetic group. In this case, the degradation of citrate is mediated via the transient formation of citryl-CoA which is cleaved to oxaloacetate with regeneration of acetyl-CoA.

\section{PROTEIN PURIFICATION AND IMMUNOLOGICAL PROPERTIES}

Citrate lyases from several micro-organisms have been purified and shown to be complexes of about $500000-600000 \mathrm{Da}$ $[1,20,28,32,33]$. They exhibit the same subunit stoichiometry $\left(\alpha_{6} \beta_{6} \gamma_{6}\right)$. The citrate lyase of $E$. coli differs from the others and was found to have a ratio of $\alpha: \beta: \gamma$ subunit of 6:6:1 [28] (table I). The first citrate 
lyase purified from a lactic acid bacterium was that of Lactococcus lactis subsp. diacetylactis [22, 32]. The native enzyme has a molecular mass of $585000 \mathrm{Da}$ and the three subunits have about the same size as these other citrate lyases. We have purified and characterized, in our laboratory, the citrate lyase of Leuconostoc mesenteroides subsp. cremoris (Bekal, personal communication). The enzyme exhibits the same general subunit stoichiometry and the subunits have a molecular mass slightly lower than lactococcal subunits (table I).

Citrate lyases from the different bacterial genus are immunologically distinct and do not cross-react. Antibodies directed against citrate lyase from Clostridium sphenoides react with the enzyme from other clostridia species but never with the proteins from Rhodocyclus gelatinosus, Klebsiella pneumoniae or Lactococcus lactis [36]. Antibodies against citrate lyase from $K$. pneumoniae do not react with protein from Lactococcus. In contrast, crossreactions were observed between lactic acid bacteria from different species and genera. Monoclonal antibodies directed against $\alpha$ - and $\beta$-subunits of Lactococcus lactis citrate lyase cross-react with citrate lyase subunits from different lactococcal species [10] and Leuconostoc mesenteroides. Polyclonal antibodies directed against $\alpha$-and $\beta$-subunits of Leuconostoc mesenteroides subsp. cremoris reacted with the corresponding citrate lyase subunits from other Leuconostoc and lactococcal species (Bekal, personal communication).

\section{REGULATION OF THE CITRATE LYASE ACTIVITY}

In citrate-utilizing bacteria which are able to synthesize $L$-glutamate via the reactions of the tricarboxylic acid cycle and therefore which contain citrate synthase, a strict regulation of citrate lyase activity is necessary to avoid a futile cycle between citrate fermentation and the $L$-glutamate synthesis pathway $[2,3]$. After citrate depletion from the growth medium $L$-glutamate synthesis via the citrate synthase reaction can be ensured only if the citrate fermentation pathway is turned off. The intracellular concentration of $L$-glutamate plays an important role in the control of citrate lyase activity. In some bacteria, a mode of regulation of citrate metabolism besides the induction and repression of enzyme is the deacety-

Table I. Molecular mass of citrate lyase subunits purified from different bacteria.

Tableau I. Masses moléculaires des sous-unités de la citrate lyase purifiée de différentes sources bactériennes.

Subunits molecular mass (Da)

\begin{tabular}{|c|c|c|c|}
\hline & & & \\
\hline & $\alpha$-Subunit & $\beta$-Subunit & $\gamma$-Subunit \\
\hline K. aerogenes ${ }^{1}$ & 54000 & 32000 & 10000 \\
\hline S. faecalis ${ }^{2}$ & 54000 & 37000 & 14000 \\
\hline R. gelatinosa ${ }^{3}$ & 55600 & 31600 & 11400 \\
\hline C. sphenoides ${ }^{4}$ & 56000 & 32000 & 11700 \\
\hline E. coli $^{5}$ & 54000 & 32000 & 85000 \\
\hline L. diacetylactis ${ }^{6}$ & 54000 & 35000 & 12000 \\
\hline Ln. mesenteroides ${ }^{7}$ & 55000 & 33000 & 10000 \\
\hline
\end{tabular}

${ }^{1}[11,33] .{ }^{2}$ [20]. ${ }^{3}$ [17], ${ }^{4}$ [1]. ${ }^{5}$ [28]. ${ }^{6}$ [32]. ${ }^{7}$ Bekal, personal communication. 
lation of ACP catalyzed by a specific citrate lyase deacetylase. The CL-deacetylase functions as an S-acetyl enzyme thioester hydrolase, and catalyses the conversion of the S-acetyl form of citrate lyase into the inactive sulfhydryl form by hydrolysis of the acetyl-thioester bonds of the prosthetic group [16]. The CL-deacetylase was first detected in $R$. gelatinosus which utilizes citrate rapidly under anaerobic conditions in the presence of light $[15,16]$. After exhaustion of citrate from the medium, the intracellular concentration of $L$-glutamate decreased and the futile cycle was avoided by inactivation of citrate lyase by the CL-deacetylase. In the presence of citrate, the CL-deacetylase is strongly inhibited and the deacetylated citrate lyase (HS-form) is converted to the active form (acetyl-S-form) by the CL-ligase. In Klebsiella, Lactococcus and Leuconostoc, a CL-deacetylase activity is not detected [21, 22].

Another mechanism of citrate lyase activity regulation has been demonstrated in C. sphenoides. A two-step process, which involves configurational changes and deacetylation is responsible for the inactivation of citrate lyase after citrate utilization from the growth medium. The citrate lyase is inactivated not simply by deacetylation but also by modulation of its conformation. The enzyme is active only in the presence of glutamate which interacts directly with citrate lyase. This modification is catalyzed by a citrate lyase inactivating enzyme (CL-IE) which has only been detected so far in this organism [4]. A protein kinase and a phosphatase modulate the activation and deactivation of citrate lyase ligase [4]. In the presence of $L$-glutamate, the CL-ligase is phosphorylated (activated) by a phospho kinase. The phosphorylated CL-ligase converts inactive citrate lyase (sulfhydryl form) into active citrate lyase (acetyl form). After citrate depletion, the CL-ligase is dephosphorylated then citrate lyase is inactiva- ted and $L$-glutamate can be synthetized via the reactions of tricarboxylic acid cycle.

In micro-organisms like lactic acid bacteria in which the citrate synthase activity is not detected, the citrate lyase system does not need to be regulated. However, the citrate lyase activity in Leuconostoc is detected only in citrate-grown cells and so is an inducible enzyme [27]. This contrasts with the finding for Lactococcus lactis subsp. diacetylactis where the enzyme is constitutive [19]. We demonstrated that addition of citrate to culture of Leuconostoc resulted in an important increase of the specific activity of citrate lyase (data not shown). After citrate exhaustion from the medium, the citrate lyase activity decreased until disappearance. No reactivation could be obtained by enzymatic or chemical acetylation suggesting that citrate lyase inactivation was not caused by deacetylation. When cells of Lactococcus or Leuconostoc are transferred from a citrate medium to a citratefree medium the citrate lyase activity of Leuconostoc cultures decreases rapidly (figure 2). The loss of activity can reach $80 \%$ of initial activity after $3 \mathrm{~h}$ of growth. In contrast, the L. lactis subsp. diacetylactis citrate lyase is more stable and looses less than $30 \%$ of its initial activity (figure 2). Mechanisms involved in the regulation of citrate lyase from these lactic acid bacteria are unknown.

\section{GENETIC ORGANIZATION}

The first citrate lyase genes cluster was identified and characterized from $K$. pneumoniae [6]. In this organism, the three enzymes which are specifically required for uptake and catabolism of citrate under anaerobic conditions are: a $\mathrm{Na}^{+}$dependent citrate carrier (citS), citrate lyase (citDEF) and oxaloacetate decarboxylase (oadGAB). These are clustered 


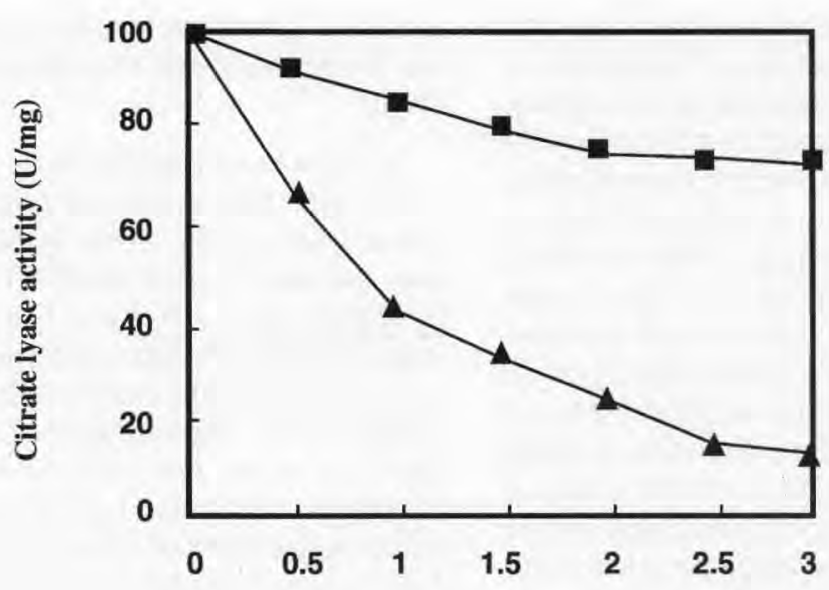

Time (h)

Figure 2. Evolution of citrate lyase activity in Leuconostoc mesenteroides subsp. cremoris 195 and Lactococcus lactis var diacetylactis 176 cells growing in citrate-free medium. For each culture, cells were first grown on citrate-medium, washed with tryptone-sel then transferred in citrate free-medium.

Figure 2. Comparaison de la stabilité de l'activité citrate lyase chez Leuconostoc mesenteroides subsp. cremoris 195 et Lactococcus lactis var. diacetylactis 176. Les cellules sont d'abord cultivées sur milieu contenant du citrate. Après centrifugation et lavages avec du tryptone-sel les cellules sont transférées dans un milieu sans citrate.

on the chromosome. The citD, citE and citF genes encode for the subunits $\gamma$ (ACP), $\beta$ (citryl-S-ACP lyase) and $\alpha$ (citrate: acetyl-ACP transferase) respectively. Upstream of citDEF, the gene citC encoding for a citrate lyase ligase was found. Another open reading frame ( $\mathrm{cit} G$ ) was identified downstream of citDEF. However, the function of the cit $\mathrm{G}$ encoded protein is unknown. The citCDEFG genes are located upstream and divergent from the citS-oadGAB genes (figure 3).

The whole-genome random sequencing of Haemophilus influenzae [14] has permitted to identify a citCDEFG gene cluster which exhibits the same organization as $K$. pneumoniae. However, no genes encoding for citrate transport were located in the upstream and downstream regions of the citCDEFG cluster. In this organism, two genes, lip $A$ and $\operatorname{lip} B$ encoding for lipoate biosynthesis protein $\mathrm{A}$ and protein
$B$ respectively, are located upstream, citC. Downstream, citG, the gene sodiTl encoding 2-oxoglutarate malate translocator was identified.

The purification of citrate lyase of $\mathrm{Leu}$ conostoc mesenteroides and an approach based on reverse genetics allowed us to clone the full-length sequence of citrate lyase genes encodeding for the $\alpha, \beta$, and $\gamma$. The gene cluster encoding citrate lyase of Leuconostoc mesenteroides is organized in three overlapping open reading frames, citD, citE and citF. The citC and citG genes were located respectively upstream and downstream of the citDEF cluster.

These results show that the citCDEFG organization is conserved in the Gramnegative and Gram-positivebacteria studied and that cit $G$ is probably involved in citrate metabolism and mainly in citrate lyase activity. The DNA fragment car- 


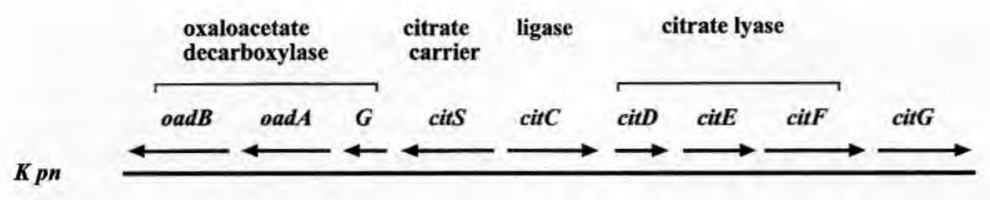

$\boldsymbol{H}$ in

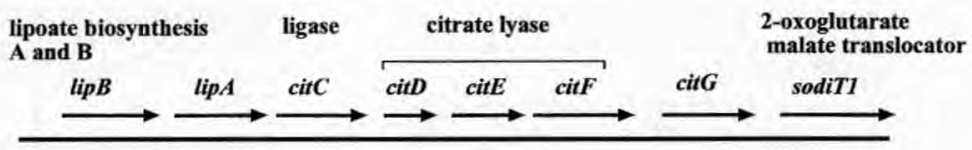

$\boldsymbol{L} \boldsymbol{m c}$

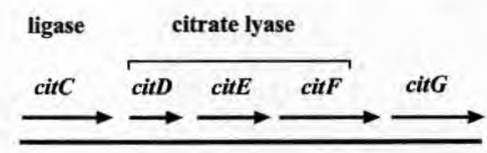

Figure 3. Genetic organization of citCDEFG cluster and the neighboring regions in Klebsiella pneumoniae (K. pn.), Haemophilus influenzae (H. in.) and Leuconostoc mesenteroides subsp. cremoris (Lmc.).

Figure 3. Organisation génétique du groupe de gènes citCDEFG chez Klebsiella pneumoniae (K. pn.), H. influenzae influenzae (H. in.) et Leuconostoc mesenteroides subsp. cremoris (Lmc.).

rying the citCDEFG gene cluster of Lc. mesenteroides subsp. cremoris was subcloned, sequenced and expressed in E. coli (Bekal, personal communication). The citCDEFG neighboring regions are not yet explored and the identification of other genes involved in citrate utilization and regulation is in progress.

\section{REFERENCES}

[1] Antranikian G., Klinner C., Kummel A., Schwanitz D., Zimmermann T., Mayer F., Gottschalk G., Purification of $L$-glutamatedependent citrate lyase from Clostridium sphenoides and electron microscopic analysis of citrate lyase isolated from Rhodopseudomonas gelatinosa, Streptococcus diacetilac. tis and C. sphenoides, Eur. J. Biochem. 126 (1982) 35-42.

[2] Antranikian G., Gottschalk G., Copurification of citrate lyase and citrate lyase ligase from Rhodopseudomonas gelatinosa and subsequent separation of the two enzymes, Eur. J. Biochem. 126 (1982) 43-47.

[3] Antranikian G., Herzberg C., Gottchalk G., In vivo dephosphorylation of proteins in Clostridium sphenoides, FEMS Microbiol. Lett. 27 (1985) 135-138.
[4] Antranikian G., Gottschalk G., Phosphorylation of citrate lyase ligase in Clostridium sphenoides and regulation of anaerobic metabolism in other bacteria, Biochemistry 71 (1989) 1029-1037

[5] Beyreuther K., Bohmer H., Dimroth P., Amino-acid sequence of citrate-lyase acylcarrier protein from Klebsiella aerogenes,Eur. J. Biochem 87 (1978) 101-110.

[6] Bott M., Dimroth P., Klebsiella pneumoniae genes for citrate lyase and citrate lyase ligase: localization, sequencing, and expression, Mol. Microbiol. 14 (1994) 347-356.

[7] Bowien S., Gottschalk G., Purification and properties of citrate lyase ligase from Streptococcus diacetylactis, Eur. J. Biochem. 80 (1977) 305-311.

[8] Buckel W., Buschmeier V., Eggerer H., The action mechanism of citrate lyase from Klebsiella aerogenes, Hoppe Seylers Z. Physiol. Chem. 352 (1971) 1195-1205.

[9] David S., van der Rest M.E., Driessen A.J.M., Simons G., de Vos W.M., Nucleotide sequence and expression in Escherichia coli of the Lactococcus lactis citrate permease gene, J. Bacteriol. 172 (1990) 5789-5794.

[10] David P., Suivi de la fermentation par dosage immunochimique d'un marqueur de croissance bactérienne : la citrate lyase, Thèse Université Technologique de Compiègne (1991). 
[11] Dimroth P, Eggerer H., Evaluation of the protein components of citrate lyase from Klebsiella aerogenes, Eur. J. Biochem. 53 (1975) 227-235

[12] Dimroth P., The prosthetic group of citratelyase acyl-carrier protein, Eur, J. Biochem. 64 (1976) 269-281

[13] Dimroth P., Bacterial sodium ion-coupled energetics, Antonie Van Leeuwenhoek 65 (1994) 381-395.

[14] Fleischmann R.D., Adams M.D., White O. Clayton R.A., Kirkness E.F., Kerlavage A.R. Bult C.J. Tomb J.F., Dougherty B.A., Merrick J.M., Mckenney K., Sutton G., Fitzhugh W., Fields C.A., Gocayne J.D., Scott J.D. Shirley R., Liul I., Glodek A., Kelley J.M., Weidman J.F., Phillips C.A., Spriggs T., Hedblome E., Cotton M.D., Utterback T.R., Hanna M.C., Nguyen D.T., Saudek D.M. Brandon R.C., Fine L.D., Fritchman J.L., Fuhrmann J.L., Geoghagen N.S.M., Gnehm C.L., McDonald L.A., Small K.V., Fraser C.M., Smith H.O., Venter J.C., Whole genome random sequencing and assembly of Haemophilus influenzae Rd. Science 269 (1995) 496-512.

[15] Giffhorn F., Beuscher N., Schaab C., Gottschalk G., Activation and inactivation of citrate lyase during growth of Rhodopseudomonas gelatinosa in citrate medium, Hoppe Seylers Z. Physiol. Chem. 353 (1972) 1518.

[16] Giffhorn F., Gottschalk G., Effect of growth conditions on the activation and inactivation of citrate lyase of Rhodopseudomonas gelatinosa, J. Bacteriol. 124 (1975) 1046-1051.

[17] Giffhorn F., Gottschalk G., Crystallization and subunit composition of citrate lyase of Rhodopseudomonas gelatinosa, FEBS Lett. 96 (1978) 175-178.

[18] Giffhorn F., Kuhn A., Phototrophic growth on citrate and regulation of citrate in three strains of Rhodopseudomonas palustris. FEMS Microbiol. Lett. 7 (1980) 225-228.

[19] Harvey R.J., Collins E.B., The citratase of Streptococcus lactis subsp. diacetylactis, J. Biol. Chem. 238 (1963) 2648-2653.

[20] Hiremath S.T., Paranjpe S., SivaRaman C., Purification and properties of citrate lyase from Streptococcus faecalis, Biochem. Biophys. Res. Commun. 72 (1976) 1122-1128.

[21] Kulla H., Gottschalk G., Energy-dependent inactivation of citrate lyase in Enterobacter aerogenes, J. Bacteriol. 132 (1977) 764-770.

[22] Kummel A., Behrens G., Gottschalk G.. Citrate lyase from Streptococcus diacetylactis. Association with its acetylating enzyme, Arch. Microbiol. 102 (1975) 111-116.

[23] Lhotte M.E., Guzzo J., Dartois V., Prévost H., Diviès C., Nuleotide sequence of citrate permease gene of Leuconostoc mesenteroides subsp. mesenteroides 19D, Genebank accession number L29572, (1995).
[24] López P., Drider D., Garcia-Quintans N., Corrales M.A., Magni C., Martin M., de Mendoez D., Regulation of expression of the Lactocuccus latis subp. lactiq biovar diacetylactis citrate transport system. Lait 78 (1998) 11-16.

[25] Marty-Teysset C., Lolkema J. S., Schmitt P., Divies C., Konings W.N., Membrane potential-generating transport of citrate and malate catalyzed by CitP of Leuconostoc mesenteroides, J. Biol. Chem. 270 (1995) 25370-25376.

[26] Marty-Teysset C.. Posthuma C., Lolkema J.S., Schmitt P., Diviès C., Konings W.N., Proton motive force generation by citrolactic fermentation in Leuconostoc mesenteroides, J. Bacteriol, 178 (1996) 2178-2185.

[27] Mellerick D., Cogan T.M.. Induction of some enzymes of citrate metabolism in Leuconostoc lactis and other heterofermentative lactic acid bacteria, J. Dairy Res. 48(1981) 497-502.

[28] Nilekani S,, SivaRaman C., Purification and properties of citrate lyase from Escherichia coli, Biochemistry 22 (1983) 4657-4663

[29] Oppenheimer N.J., Singh M., Sweeley C.C., Sung S.J., Srere P.A., The configuration and location of the ribosidic linkage in the prosthetic group of citrate lyase, Biol. Chem. 254 (1979) 1000-1002.

[30] Robinson J.B.Jr., Singh M., Srere P.A., Structure of the prosthetic group of Klebsiella aerogenes citrate (pro-3S)-lyase, Proc. Natl. Acad. Sci. U.S.A. 73 (1976) 1872-1876.

[31] Schmellenkamp B., Eggerer H., Mechanism of enzymic acetylation of desacetyl citrate lyase, Nat Acad. Sci. 71 (1974) 1987-1991.

[32] Singh M., Srere PA., Purification and properties of citrate lyase from Streptococcus diacetylactis, J. Biol. Chem, 250 (1975) 5818-5825.

[33] Singh M., Srere P.A., Klapper D.G., Capra J.D., Subunit and chemical composition of citrate Jyase from Klebsiella pneumoniae, Eur. J. Biochem. 251 (1976) 2911-2915.

[34] Singh M., Robinson J.B., Srere P.A., On the structure of the prosthetic group of citrate (pro-3S)-lyase, J. Biol. Chem. 252 (1977) 6061-6068.

[35] Srere P.A., The citrate enzymes: their structures, mechanisms, and biological functions, Curr. Top Cell. Regul. 5 (1972) 229-283.

[36] Subhalakshmi S., SivaRaman C., Bacterial citrate lyase, J. Biosci 6 (1984) 379-401.

[37] Vaughan E.E., David S., Harrington A., Daly C., Fitzgerald G.F., De Vos W.M., Characterization of plasmid-encoded citrate permease $($ citP) genes from Leuconostoc species reveals high sequence conservation with the Lactococcus lactis citP gene, Appl. Environ. Microbiol. 61 (1995) 3172-3176. 